\title{
Species diversity, structure and dynamics of two populations of an endangered species, Magnolia dealbata (Magnoliaceae)
}

\author{
Lázaro R. Sánchez-Velásquez ${ }^{1,2}$ \& María del Rosario Pineda-López ${ }^{1}$ \\ 1 Laboratorio de Biotecnología y Ecología Aplicada, Dirección General de Investigaciones, Universidad Veracruzana, \\ Campus para la Cultura, las Artes y el Deporte, Av. de las Culturas Veracruzanas No. 101, Col. Zapata, AP 250, \\ Xalapa, Ver., CP 91090, México. Tel.: (+52) (228) 842-277 \\ 2 lasanchez@uv.mx
}

Received 14-IX-2003. C Corrected 15-VII-2005. Accepted 09-III-2006.

\begin{abstract}
Little is known about the ecology and demography of the genus Magnolia. Magnolia dealbata Zucc. is an endangered species endemic to Mexico. Two contrasting populations of M. dealbata (one from the grasslands and other from a secondary cloud forest) were studied. We asked the following questions: (a) Are size structure (diameter at breast height, DBH) and infrutescence production significantly different between the two populations? (b) What are the populations' growth rates ( $\lambda$ ) based on an initial 1987 study? (c) Are the associated species diversity indices of these $M$. dealbata populations significantly different? The results show no significant differences between the population size structure $(\mathrm{p}=.094)$; the growth rates of the populations were 0.992 in grassland and 1.053 in secondary cloud forest. The number of infrutescences produced in year 2001 and DBH relationship were significantly linear $(\mathrm{p}<.001)$ in both populations, and there was no significant difference ( $p>.01$ ) between their slopes. The diversity indices were not significantly different ( $p>.05$ ), and only $54 \%$ of the species were common to both sites. Our study suggests that both populations are relatively stable and that the management history could impact more on the species composition than on the diversity indices. Rev. Biol. Trop. 54 (3): 997-1002. Epub 2006 Sept. 29.
\end{abstract}

Key words: cloud forest, diversity, endangered species, infrutescences, Magnolia dealbata, Mexico, population.

Few population studies have been done on the genus Magnolia (eg Weaver 1987, Doyle 1989, Gutiérrez 1993). Seven species and two subspecies of Magnolia are native to Mexico (Vázquez 1994): M. iltisiana and $M$. schiedeana are classified as threatened species, and M. dealbata and M. sharpii are classified as endangered according to IUCN and Federal Mexican laws. Magnolia dealbata is endemic to Mexico and it is actually restricted to small local populations in the states of Oaxaca, Hidalgo, San Luis Potosí and Veracruz. Coyopolan, Veracruz has the highest number of individuals (Pattison 1985, Gutierrez 1993). A recent study reported a new locality for $M$. dealbata in the state of Querétaro, but it did not describe the condition of the population (Cartujano et al. 2002).

$M$. dealbata wood is utilized as firewood and fence material. Its giant white flowers are used ornamentally and for traditional medicine (Gutierrez and Vovides 1997). Indigenous Mexicans know $M$. dealbata as Eloxochitl (from nahuatl elotl ear and xochitl flower) (Pattison 1985). M. dealbata usually grows in cloud forest or "bosque mesófilo de montaña" (Rzedowski 1978).

Gutierrez and Vovides (1997) described the annual survivorship of two $M$. dealbata populations from Coyopolan, Veracruz, based on data from 1986 to 1987 (L. Gutiérrez, pers. com.). There are no other studies published on 
the present population status of this rare species. Similarly, there are no descriptions or listings of the species associated with $M$. dealbata.

Information on population structure and size is useful, even from short-term studies, to allow us to make inferences about the past and future of a particular population (Martínez-Ramos and Álvarez-Buylla 1995, Sánchez-Velásquez et al. 2002). Our study is a preliminary investigation of a long-term study in which the general objective is to document the perturbation impact on the demography of $M$. dealbata in Coyopolan, Veracruz, México. Two ecologically contrasting populations of $M$. dealbata were studied (grassland and secondary cloud forest) with the following questions to test: (a) Are the size structure (DBH) and infrutescences production significantly different in both populations? (b) What are the populations' growth rates $(\lambda)$ based on the initial study of Gutiérrez from 19861987? (c) Are the associated species diversity indices of the $M$. dealbata populations significantly different?

\section{MATERIALS AND METHODS}

M. dealbata, a member of Section Rytidospermum, is a deciduous tree that grows to $25 \mathrm{~m}$ in height, has white large flowers measuring $20 \mathrm{~cm}$ and leaves $80 \mathrm{~cm}$ long. Each adult tree is able to produce several new stump sprouts after they have been cut, but only one or two principal stems will survive. These attributes produce no clear relationship between age and size, as we found an old tree with a small stem as well as an old tree with a large stem. Altitudinal distribution of M. dealbata is from 1200 to $1500 \mathrm{~m}$, Pattison (1985), Johnson (1989), Vázquez (1994), Qiu et al. (1995), Vovides and Iglesias (1996), Gutiérrez and Vovides (1997), Azuma et al. (2001) and Kim et al. 2001, for more details of its ecology, taxonomy and phylogeny.

We studied two populations of $M$. dealbata in Coyopolan, Veracruz, México $\left(19^{\circ} 21^{\prime}\right.$ $\mathrm{N}, 97^{\circ} 04^{\prime} \mathrm{W}$ ), one located in secondary cloud forest and the other in grassland. Both were previously studied during 1986-1987 by Gutiérrez (1993), but we did not find the exact location of the originals plots. The climate in this area is subtropical, with rainfall of 1500 $2000 \mathrm{~mm}$ annually distributed throughout the year. The average annual temperature is $19.5^{\circ} \mathrm{C}$ (Gutiérrez and Vovides 1997). Eight random plots $(10 \times 10 \mathrm{~m})$ were used for each population (a total of 16), accounting for all individuals of $M$. dealbata. Other species included were only those $\geq 1.3 \mathrm{~m}$ in height; species, DBH and height were registered. Our plot size was larger than the size of the largest cluster $(6 \times 5 \mathrm{~m})$ of M. dealbata found (Gutiérrez 1993). Number of infrutescences produced by individuals of $M$. dealbata was counted. Each individual $M$. dealbata seedling was mapped and labeled for a subsequent demography study.

The size structure between both populations was analyzed by Spearman correlation coefficient (Zar 1999). Dependence between size classes of $M$. dealbata vs. sites was determined by Fisher test exact.

The $\chi^{2}$ test was used to find independence (total number of individuals of $M$. dealbata) between sites and year (years 1987 and 2002). Previously, the registered data was recorded as the number of individuals per hectare. The annual population growth rate $(\lambda)$ was calculated in both populations by using the equation:

$$
N_{t}=N_{0} \lambda^{t}
$$

were $N_{t}$ is population size in time $t$ (until year 2001), $N_{o}$ is initial population size (year 1987), $\lambda$ is population growth rate and $t$ is time (14 years). Hence $\lambda$ value can be estimated by

$$
\lambda=\sqrt[t]{\frac{N_{t}}{N_{0}}}
$$

The infrutescences number $v s$. DBH size was analyzed by linear simple regression in both $M$. dealbata populations (DBH as independent variable).

Shannon-Wiener diversity indices were calculated for both sites using the equation:

$$
H^{\prime}=-\sum_{i=1}^{s}\left(p_{i}\right)\left(\log _{2} p_{i}\right)
$$


where $s$ is species number; $p_{i}$ is proportion of species $i$-th. The diversity indices were compared with Student's T test (Zar 1999, SánchezVelásquez and Pineda-López 2000). We used individuals $>1.3 \mathrm{~m}$ height. The structure of plant species community associated with $M$. dealbata was analyzed through $\chi^{2}$ test.

\section{RESULTS}

The size structure between both populations was not significantly correlated (Fig. 1) (Spearman, $\mathrm{p}=.094$ ), nor was size structure $v s$. sites significantly dependent (Fisher, $\mathrm{p}=.276$ ).

In the 1986-1987 study, the number of individuals of $M$. dealbata per hectare was 338 and 554 in grassland and secondary cloud forest, respectively (Gutiérrez 1993), while in this study (2001) was 300 in grassland and 1137 in secondary cloud forest. The total number of individuals of $M$. dealbata between sites and years was not independent $\left(\chi^{2}, \mathrm{p}<.001\right)$. The population growth rate in grassland was 0.992 , while in secondary cloud forest was 1.053 .

Linear regression analysis between relationship of the number of infrutescences and DBH was significant in both populations; grassland $\left(N c=-7.28+1.556 \mathrm{DBH} ; r^{2}, \mathrm{p}<.001\right)$ and secondary cloud forest $(N c=-5.11+1.549$ $\left.\mathrm{DBH} ; r^{2}, \mathrm{p}<.001\right)$. However, the slopes were not significantly different between populations (Student's T, p>.1).

The diversity index was not significantly different between sites (Student's T, p>.05; secondary cloud forest $H^{\prime}=2.62$ and grassland $\left.H^{\prime}=2.84\right)$. Nevertheless, only $54 \%$ of the species were common to both sites (year 2001). Five species from grassland were not found in secondary cloud forest, while two species from secondary cloud forest were not established in grassland (Fig. 2).

\section{DISCUSSION}

The size structure in both $M$. dealbata populations was an inverse $J$ type. This is

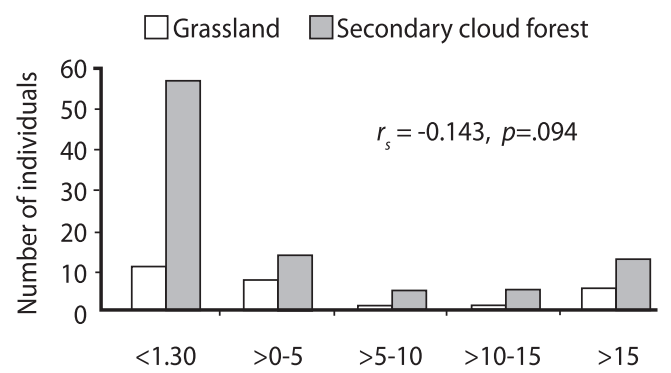

Height $(\mathrm{m}) \quad$ Diameter brast height $(\mathrm{cm})$

Fig. 1. Size structure of two Magnolia dealbata populations in Coyopolan, Ixhuacán de los Reyes, Veracruz, Mexico.

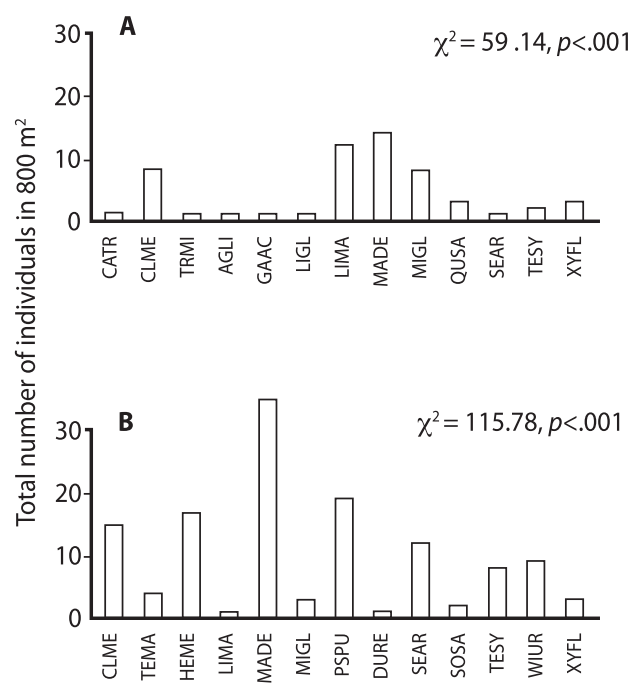

Fig. 2. Floristic composition associated with Magnolia dealbata (MADE), individuals > $1.3 \mathrm{~m}$ tall. a) Grassland, b) Secondary cloud forest. Carpinus tropicalis (CATR), Clethra mexicana (CLME), Trema micrantha (TRMI), Ageratina ligustrina (AGLI), Gaultheria acuminata (GAAC), Litsea glaucescens (LIGL), Liquidambar macrophylla (LIMA), Miconia glaberrima (MIGL), Quercus sartorii (QUSA), Senecio arborecens (SEAR), Ternstroemia sylvatica (TESY), Xylosma flexuosum (XIFL), Tetrachyron manicatum (TEMA), Hedyosmum mexicanum (HEME), Psychofria pubescens (PSPU), Solanum salvifolium (SOSA), Wigandia urens (WIUR), Duranta repens (DURE).

typical for many natural populations of tree species (Vanclay 1994) and shade tolerant species. This type of curve, in which age and size are not correlated, suggests that there are more environmentally poor conditions than rich for the growth of individuals (Martínez-Ramos and 
Álvarez-Buylla 1995). However, we infer in our study that this is not the case: from almost all the individuals that had been cut recently at the base emerged more small individuals than large. As mentioned earlier, M. dealbata can sprout several stems after it has been cut, but only one or two principal sprouts survive (pers. obs.). We could identify sprouts because some individuals had evidence of cuttings. Similarly, the size structure of the population ( $J$ inverse and non relationship between agesize) of Magnolia splendens was observed in the Luquillo mountains of Puerto Rico (Weaver 1987) and also in M. macrophylla in the Mill Creek Forest,USA (Doyle 1989).

In the secondary cloud forest the population growth rate $(\lambda)$ of $M$. dealbata was estimated at a $5.4 \%$ annual population increase, ie $\lambda=1.054$. This suggests a good history of in situ conservation management and also $\lambda>1$ is typical of a shade tolerant species (Vanclay 1995). Nevertheless, the grassland population of $M$. dealbata (an open area and frequently used for cow grazing) showed a slight annual population decrease, a $1 \%$ annual loss. However, more details and time are necessary to understand the perturbation impact on population dynamics of $M$. dealbata. Weaver (1987) found inversed results: he registered an $18 \%$ population increase of $M$. splendens in clear cut sites, while in sites without clear cutting, he found a $M$. splendens population decrease of $35 \%$ in 35 years. There have been other studies in Mexico of two evergreen species; briefly, M. sharpii is a local endangered species in Los Altos de Chiapas (González et al. 1997) and M. iltisiana is a threatened species with low regeneration and few individuals in the Western Sierra de Manantlán of Mexico (Vázquez et al. 1995, Saldaña-Acosta et al. 2001).

The significant linear regression of $\mathrm{DBH}$ $v s$ the infrutescences number within each of the populations and the lack of significant difference between the slopes implies that $M$. dealbata individuals produce more infrutescences as size increases. This characteristic is common in nature because the tallest individual captures more resources than the shorter individuals, and in turn produces more infrutescence. Future demography studies or conservation agencies can use these models (relationship DBH-Infrutescences number) to forecast future production of seeds.

We found more species simultaneously with $M$. dealbata (19) than the six cited in Gutiérrez and Vovides (1997), but we did not find Tilia $s p$. as they reported. Perhaps, we found more species because we used smaller size DBH than they did.

Diversity index comparisons of the different studies have some limitations (SánchezVelásquez et al. 2002b) because: 1) different sample size, plot size and diversity index are used, and 2) the minimum size of the individuals used are different. However, with these limitations we can observe that our index values are in the intervals of those found in other studies of Mexican cloud forests, but our values are higher than their average values: Sierra de Manantlán Biosphere Reserve (H' from 3.2 to 0.59 , with $5 \mathrm{~cm}$ of DBH minimum) (Santiago and Jardel 1993, Hernández et al. 2000), El Cielo Biosphere Reserve (H' from 3.6 to 0.39 , with $5 \mathrm{~cm}$ of DBH minimum)(Puig 1987), Sierra de Cucharas (H' from 3.89 to 2.81 , with $15 \mathrm{~cm}$ of DBH minimum)(Puig et al. $1983)$ and $\mathrm{El}$ Triunfo $\left(\mathrm{H}^{\prime}=3.8024\right.$, with $5 \mathrm{~cm}$ of DBH minimum)(Williams 1991).

Our study suggests that a change in management history can impact species composition more than diversity indices. Only $54 \%$ of the species were common to both plant communities associated with $M$. dealbata.

\section{ACKNOWLEDGMENTS}

Andres Vovides, Elizabeth Hulstrand, Antonio Andrade-Torres, Luis Manuel Martínez Rivera, Irene Masquina and two anonymous individuals reviewed the manuscript. Vicente Vázquez and Rene A. Palestina-Guerrero determined the scientific name of plants collected. Thanks to Aron, Abdon and Candido from the Coyopolan community, José Luis Herrador 
and Liliana Gutiérrez for their assistance on our first field visits. Mario Fernández and José Luis Sánchez for the logistic support in the Casa Universitaria in Coyopolan. The study was funded by Consejo Nacional de Ciencia y Tecnología -Mexico and by grants I39240-V and Universidad Veracruzana.

\section{RESUMEN}

La ecología y demografía del género Magnolia han sido poco estudiadas. Magnolia dealbata Zucc. es una especie endémica de México y es considerada en peligro de extinción. Se estudiaron dos poblaciones contrastantes de $M$. dealbata (una dentro de un pastizal y la otra dentro de vegetación secundaria del bosque mesófilo de montaña -bosque de niebla-). Buscamos respuestas a las siguientes preguntas: (a) ¿La estructura de tamaños y la producción de frutos de ambas poblaciones son significativamente diferentes? (b) ¿Cuáles son las tasas de crecimiento poblacional ( $\lambda$ ), tomando como población inicial un estudio de 1987 ? (c) ¿Son significativamente diferentes los valores de diversidad de especies de ambas poblaciones? No hallamos diferencias significativas entre la estructura de tamaños de ambas poblaciones $(p=.094)$. Las tasas de crecimiento poblacional de las poblaciones en pastizal y en el bosque secundario de neblina fueron 0.992 y 1.053 , respectivamente. El número de infrutescencias por individuo producidas en 2001 y su relación con el diámetro a la altura del pecho fueron significativamente lineales, y no hubo diferencias significativas entre sus pendientes $(p>1)$. Los índices de diversidad no fueron significativamente diferentes $(\mathrm{p}>.05)$ y sólo el $54 \%$ de las especies fueron comunes entre sitios. Las poblaciones parecen relativamente estables y el historial de manejo en ambas comunidades podría afectar más a la composición de especies que a los índices de diversidad.

Palabras clave: bosque nuboso, diversidad, especie en peligro de extinción, infrutescencia, Magnolia dealbata, México, población.

\section{REFERENCES}

Azuma, H., J. García-Franco, V. Rico-Gray \& L.B. Thien. 2001. Molecular phylogeny of the Magnoliaceae: the biography of tropical and temperate disjunctions. Am. J. Bot. 88: 2275-2285.

Cartujano, S., S. Zamudio, O. Alcántara \& I. Luna. 2002. El bosque mesófilo de montaña en el municipio de Landa Matamoros, Querétaro, México. Bol. Soc. Bot. Méx. 70: 13-43.
Doyle, A.M. 1989. Magnolia macrophylla: Population structure, reproductive strategies and the disturbance regime of Mill Creek Forest. Tesis de licenciatura, Tulane University, Louisiana, USA. 69 p.

González, E.M., G.S. Ochoa, M.N. Ramírez \& P.F. Quintana. 1997. Contexto Vegetacional y Florístico de la Agricultura, p. 85-117. In M.R. Parra V. \& B.M. Díaz H. (eds.). Los Altos de Chiapas: Agricultura y Crisis Rural. Tomo 1. Los Recursos Naturales. El Colegio de la Frontera Sur, Quintana Roo, Mexico.

Guitiérrez, L. 1993. Estudio biológico de una especie forestal endémica (Magnolia dealbata Zucc.). Tesis de maestría en ciencias, Facultad de Ciencias Biológicas, Universidad Autónoma de Nuevo León, Monterrey, Nuevo León, México. 92 p.

Gutiérrez, L. \& A. Vovides. 1997. An in situ study of Magnolia dealbata Zucc. In Veracruz State: an endangered endemic tree of Mexico, Biod. Cons. 6: 89-97.

Johnson, D.L. 1989. Nomenclatural changes in Magnolia. Baileya 23: 55-56.

Kim, S., C.W. Park, Y.D. Kim \& Y. Suh. 2001. Phylogenetic relationships in family Magnoliaceae inferred from NDHF sequences. Am. J. Bot. 88: 717-728.

Martínez-Ramos, M. \& E. Álvarez-Buylla. 1995. Ecología de poblaciones de plantas en una selva húmeda de México. Bol. Soc. Bot. Méx. 56: 121-153.

Patisson, G. 1985. Magnolia dealbata. Magnolia J. Magnolia Society 22: 17-18.

Puig, H., R. Bracho \& V. Sosa. 1983. Composición florística del bosque mesófilo en Gómez Farías, Tamaulipas, México. Biótica 8: 339-358.

Qiu, Y.L., M.W. Chase \& C.R. Parks. 1995. A chloroplast DNA phylogenetic study of the eastern Asia-eastern North America disjunct section Rytiodospermum of Magnolia (Magnoliaceae). Am. J. Bot. 82: 1582-1588.

Rzedowski, J. 1978. Vegetación de México. LIMUSA, México, DF. 432 p.

Saldaña-Acosta,A., S. Zuluaga \& E. Jardel. 2001. Germinación de Acer skutchii Rehder y Magnolia iltisiana Vázquez en la Reserva de la Biosfera Sierra de Manantlán, Jalisco, México. Foresta Veracruzana 3: 1-8.

Sánchez-Velásquez, L.R. \& M.R. Pineda-López. 2000. Ecología Cuantitativa en Plantas: Métodos. Universidad de Guadalajara, Guadalajara, Jalisco, México. 142 p.

Sánchez-Velásquez, L.R., E. Ezcurra, M. Martínez-Ramos, E. Álvarez-Buylla \& R. Lorente. 2002a. Population 
dynamics of Zea diploperennis, a perennial herbs: effect of slash and burn practice. J. Ecol. 90: 684-692.

Sánchez-Velásquez, L.R., G. Hernández, M. Carranza, M.R. Pineda-López, R. Cuevas \& F. Aragón. 2002b. Estructura arbórea del bosque tropical caducifolio usado para la ganadería extensiva en el norte de la Sierra de Manantlán, México: Antagonismo de usos. Polibotánica 13: 25-46.

Santiago, A.L. \& E. Jardel. 1993. Composición y estructura del bosque mesófilo de montaña en la Sierra de Manantlán, Jalisco-Colima. Biotam 5: 13-26.

SAS Institute. 1996. SAS/STAT user's guide. Version 6. SAS Institute, Cary, North Carolina, USA.

Vanclay, J.K. 1994. Modeling Forest Growth and Yield: Applications to Mixed Tropical Forest. CAB International, London, England. 312 p.
Vázquez, G.A. 1994. Magnolia (Magnoliaceae) in Mexico and Central America: a synopsis. Brittonia 46: 1-23.

Vázquez, G.A., R. Cuevas, T.S. Cochrane, H.H. Iltis, F. Santana \& L. Guzmán. 1995. Flora de Manantlán. SIDA, Bot. Misc., Bot. Res. Inst. Texas, Inc. 13. Universidad de Guadalajara, Guadalajara, Jalisco, México. 312 p.

Weaver, P.L. 1987. Ecological observations on Magnolia splendens urban in the Luquillo mountains of Puerto Rico. Carib. J. Sci. 23: 340-351.

Williams, L.G. 1991. Nota sobre la estructura del estrato arbóreo del bosque mesófilo de montaña en los alrededores del campamento "El Triunfo", Chiapas. Acta Bot. Mexic. 13: 1-7.

Zar, J.H. 1999. Biostatistical Analysis. Prentice-Hall, London. $663 \mathrm{p}$. 